Civil Engineering

Volume 169 Issue CE4

Happy Valley underground stormwater storage scheme, Hong Kong

Luk, Cheng and Johnson
Proceedings of the Institution of Civil Engineers Civil Engineering 169 November 2016 Issue CE4 Pages 169-175 http://dx.doi.org/10.1680/jcien.15.00050 Paper 1500050

Received 17/08/2015_Accepted 19/04/2016

Published online 17/06/2016

Keywords: floods \& floodworks/project management/ sustainability i ice Institution of Civil Engineers

\title{
Happy Valley underground stormwater storage scheme, Hong Kong
}

1 Wai-Hung Luk BSC, MPA, MHKIE, MICE, CEng Chief Engineer, Drainage Services Department, Hong Kong, PR China

2 Ellen Cheng BASc(Hons), MEng(Hons), CEng, MICE, MHKIE, BEAMPRO

Senior Engineer, Drainage Services Department, Hong Kong, PR China
3 James Johnson BSC, MRICS, MHKIS, MCIArb

Partner, Arcadis, Hong Kong, PR China
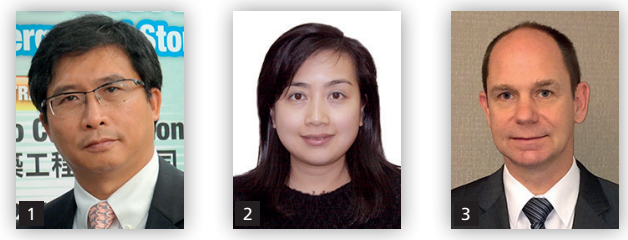

The Happy Valley underground stormwater storage scheme is designed to alleviate flood risk in Wan Chai, Hong Kong. It involves the construction of a $60000 \mathrm{~m}^{3}$ stormwater storage tank under the $\mathrm{f} 9 \mathrm{billion}$ a year Happy Valley racecourse, which has to remain operational throughout construction. It is also the largest NEC3 target cost contract undertaken in Hong Kong. The collaborative-style contract is characterised by an equitable risk-sharing mechanism, making it ideally suited for the severe site constraints and highly complex works. This paper describes how use of the NEC3 and a 'one team, one goal' approach is helping to ensure close collaboration between the employer and contractor and a successful outcome. Due for final completion in 2018, the project's first phase - completed in 2015 - has already won several local and international awards.

\section{Introduction}

Hong Kong's Wan Chai district has been hit by very heavy rainstorms and typhoons during the rainy season in recent years. These have brought record-breaking levels of precipitation to this fully urbanised and densely populated location, resulting in a flood depth of approximately $1 \mathrm{~m}$ in some areas.

The Drainage Services Department (DSD) of the Hong Kong government has therefore developed a long-term solution by constructing an underground stormwater storage tank at the Happy Valley racecourse. It is designed to reduce the risk of flooding posed to the over 150000 population in the low-lying areas of the Wan Chai district in Happy Valley and Causeway Bay.

The HK\$1.07 billion (£96million) Happy Valley underground stormwater storage scheme comprises construction of a large storage tank. It will temporarily store some of the stormwater and attenuate the peak flow through the stormwater drainage system during heavy rainstorms. When the rainstorm is over, the stored water will be discharged to the sea by way of the existing drainage system. The scheme is designed to withstand rainstorms with an intensity of a 50 year return period.

The scope includes construction of a $60000 \mathrm{~m}^{3}$ underground stormwater storage tank (equivalent to the size of 24 standard-sized swimming pools), an integrated pumping station, a $650 \mathrm{~m}$ long box culvert and associated works, a stilling basin, a fan room, access manholes, the modification of an existing box culvert, and associated drain and sewer diversion works (see Figures 1 and 2). Project information for the Happy Valley underground stormwater storage scheme is presented in Table 1.

Happy Valley is a premier residential area located just a stone's throw away from the main shopping streets and the financial

\begin{tabular}{|l|l|}
\hline Project title & $\begin{array}{l}\text { Happy Valley underground stormwater storage } \\
\text { scheme }\end{array}$ \\
\hline Contract used & $\begin{array}{l}\text { NEC3 Engineering and Construction Contract } \\
\text { option C (target contract with activity schedule) }\end{array}$ \\
\hline Employer & Drainage Services Department \\
\hline Project manager & Chief Engineer of Drainage Projects \\
\hline NEC advisor & Arcadis \\
\hline Contractor & Chun Wo Construction \& Engineering Ltd \\
\hline Start date & 3 September 2012 \\
\hline Completion date & February 2018 \\
\hline Original total of the prices & HK\$ 678million (f62 million) \\
\hline
\end{tabular}

Table 1. Project information 


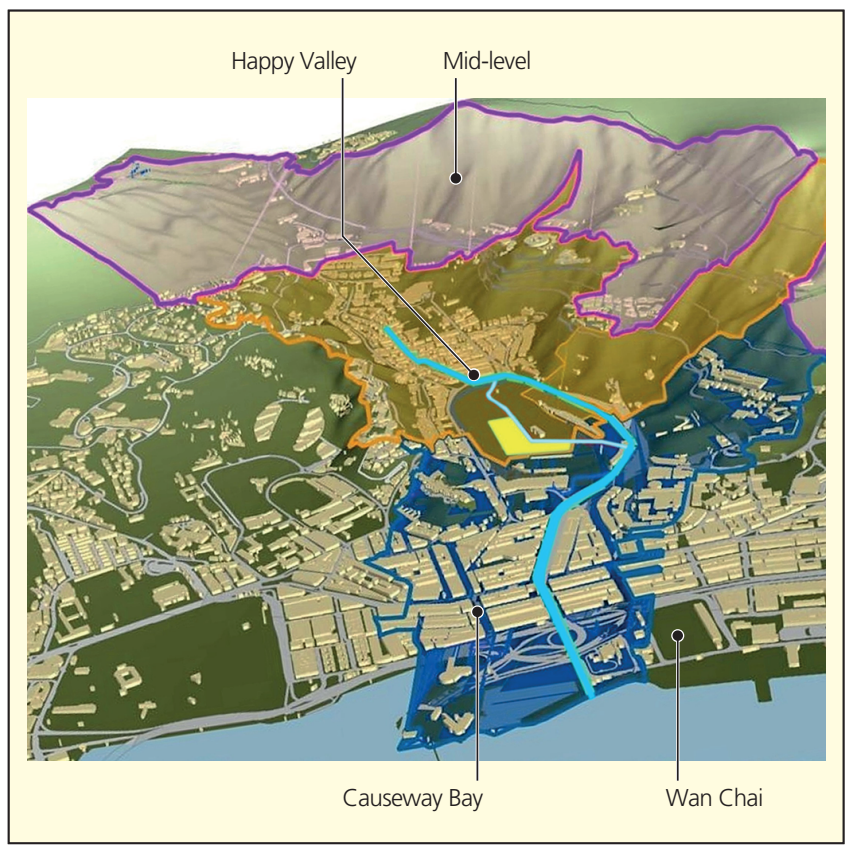

Figure 1. Model of Happy Valley catchment in Wan Chai, Hong Kong, showing new stormwater storage tank (yellow) at Happy Valley racecourse

hub of Hong Kong. The area is also renowned for its racecourse and recreation ground, attracting hundreds and thousands of horse racing enthusiasts and sports lovers every day. The Happy Valley horse racing track also bears significant commercial and social importance - horse racing raises a turnover of around HK\$ 100 billion ( $£ 9$ billion) a year in Hong Kong.

The DSD was faced with the challenge of constructing a large underground stormwater storage tank in this sensitive area. The construction works at the recreation ground and the horse racing track will inevitably affect the residents, sports pitch users and horse racing fans. Therefore, the underground stormwater storage scheme has been separated into two phases. Particular operational requirements are stipulated in the contract to accommodate the daily needs of the public and allow horse racing operations to continue unimpeded during the construction period.

\section{Procurement route}

DSD has chosen a collaborative contract - the NEC3 Engineering and Construction Contract (ECC) option C (target contract with activity schedule) - to carry out this highly complex project. Traditional procurement is considered less suitable for complex and challenging projects (Challender et al., 2014). The project draws on the invaluable experience gained and the lessons learnt from the DSD's first ECC option C contract, the Fuk Man Road nullah project, completed in 2012.

The key features of ECC option C are pain-gain share, openbook accounting, risk management, early warning and timely assessment of compensation events. In addition to these benefits, the DSD is also achieving better value from subcontractors in terms of the level of tender prices and quality of post-contract

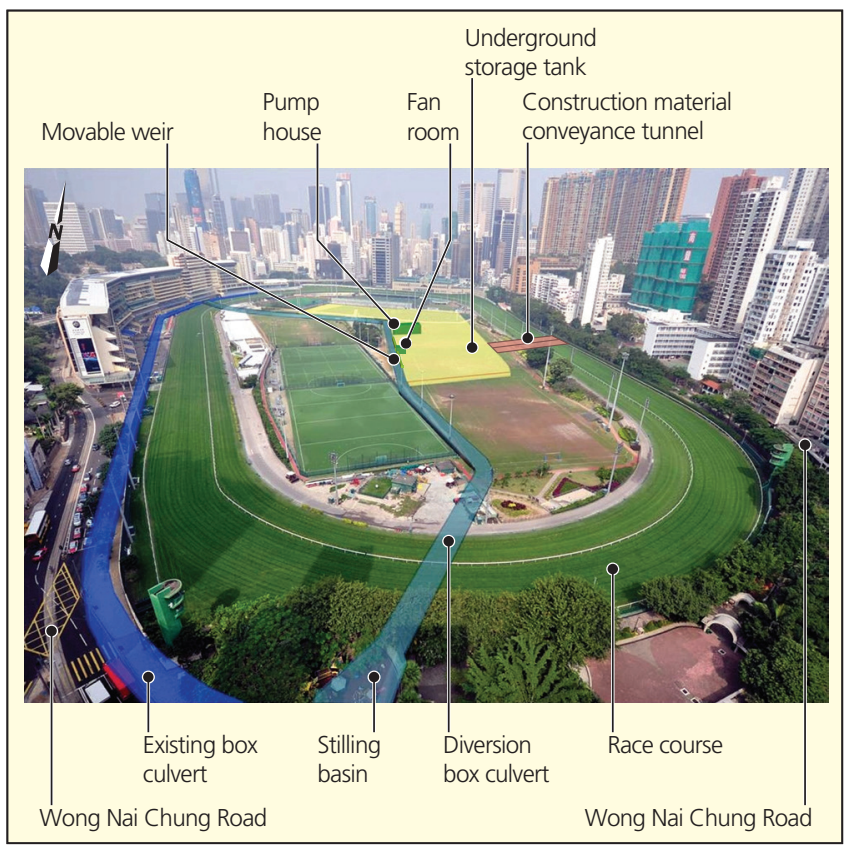

Figure 2. Aerial view of Happy Valley racecourse showing the underground stormwater storage tank and river diversion culverts

performance through implementation of a special effective subcontractor management procedure.

The procedure involves the selection of subcontractors in a competitive tendering environment, governed jointly by the project manager and the contractor. The competitiveness of the subcontractor's price maintains the competitive nature of the defined cost. To achieve these benefits in the project, the project manager has taken a more active role in the management of subcontractors than is typical in target cost contracts. This active involvement starts with subcontractor selection and continues through on-site liaison and payment to subcontract completion.

To enhance the NEC's required 'spirit of mutual trust and cooperation', the project manager has implemented some innovative measures to improve communication and embrace collaboration throughout the whole project team, principally through a ' $360^{\circ}$ communication network'. This effective and instantaneous communication platform is the essence of the 'one team, one goal' approach, and has become the key in achieving the success of this project. The details of these key features are discussed in this paper.

\section{Pain-gain share and open-book accounting}

The ECC option C contract operates an open-book account to share cost information between the project manager and the contractor that would traditionally have remained confidential in the Hong Kong government's traditional General Conditions of Contract (GCC).

The availability of real-time project financial data assists decision-making and budgetary control processes and thus allows both the contractor and the project manager to make accurate cost estimates of design changes. This is of paramount importance 
to the underground stormwater storage scheme, given its everchanging site constraints and stakeholders' requirements.

The desire to achieve common objectives is driven by the pain-gain share mechanism. This is a mechanism where any cost savings and cost overruns are shared between the employer and contractor according to pre-agreed share percentages. This pain-gain share mechanism motivates the contractor to propose innovative or alternative cost-reduction proposals in collaboration with the project manager. Both parties strived for optimal solutions with the least cost and time impact, as well as minimising disruptions to the public, especially horse racing operations.

The benefits of pain-gain share and open-book accounting are demonstrated by the innovative foundations and subsoil drainage system used in the underground stormwater storage scheme.

\subsection{Case study 1 - innovative foundations and subsoil drainage system}

The original design required 533 pre-bored socketed H-piles from $40 \mathrm{~m}$ to $60 \mathrm{~m}$ in length for the foundations of the underground storage tank. These piles would hold down the tank against the buoyancy exerted by groundwater.

At the same time, there was an agreement between the DSD and the Hong Kong Jockey Club (HKJC) that spectators' views would not be obstructed in any situation. Given that the storage tank is located directly adjacent to the horse racing track, the piling sequence and setting of the piling rigs and cranes would require careful planning.

Driven by the cost-saving initiatives under the pain-gain share mechanism, the contractor and the project manager were keen to look for alternative designs with the least implications on cost and horse racing operations.

The contractor proposed an alternative foundation design. This design optimises a series of peripheral water cut-off walls around the storage tank and a proposed subsoil drainage system underneath the footprint of the tank in order to lower the groundwater level around the tank and thus reduce buoyancy (Figure 3).

This swift decision-making process, together with the reduction in foundation construction time, has resulted in substantial time and cost savings. The alternative design works have advanced project completion by 7 months and reduced the construction cost by HK\$ 72 million ( $£ 6.6$ million), which is equivalent to $10 \%$ of the original target cost.

In addition, the new design was able to save approximately $4000 t$ of structural steel. In environmental terms, this amounts to a reduction of approximately $8000 \mathrm{t}$ of carbon-dioxide-equivalent emissions.

\section{Timely assessment of compensation events}

A compensation event is NEC terminology for variations, changes to works information, inclement weather and issues outside the control of the contractor, usually resulting in changes in time and cost.

ECC option C contracts operate a swift notificationquotation-assessment-implementation process. The strict time frame for agreeing compensation events (assisted by open-book accounting) leads to the settlement of variations around the time

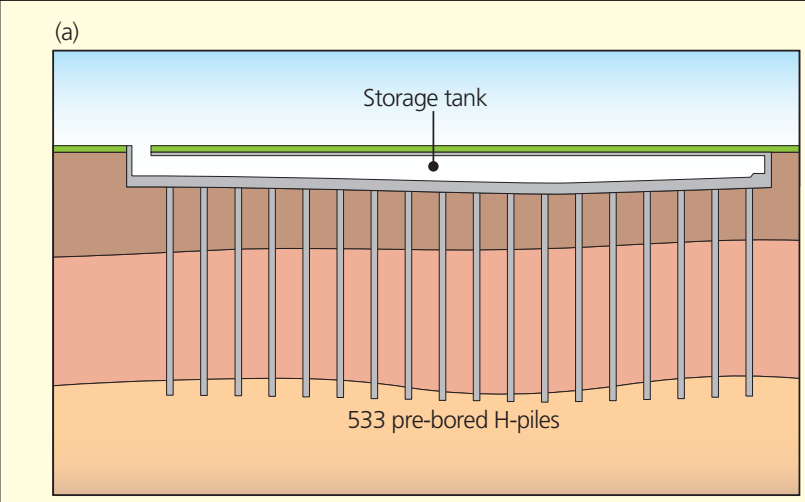

(b)

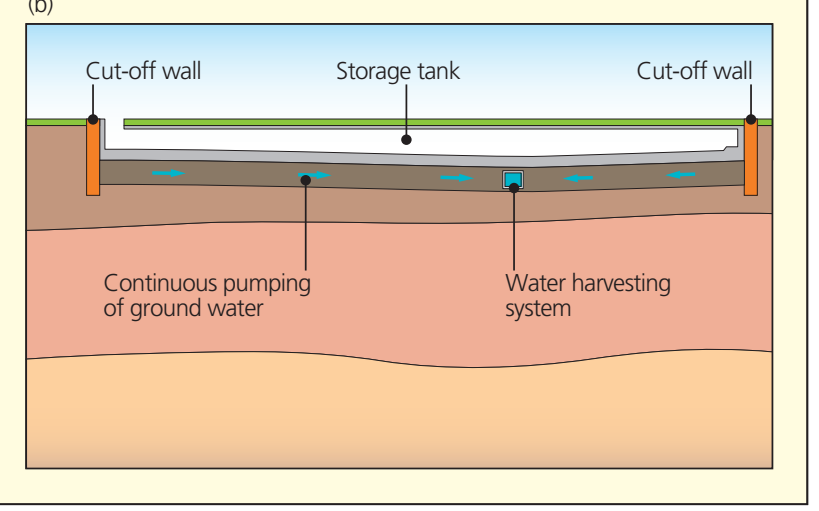

Figure 3. Original (a) and revised (b) foundation designs - using a subsoil drainage system saved 7 months and cut construction cost by $\mathrm{f} 6 \cdot 6$ million

they occur, thereby easing and speeding up the final account process

A further benefit of timely assessment of compensation events is the subsequent agreement of variations on subcontracts. This allows payment on time and early final account settlement of these subcontracts upon works completion.

In the underground stormwater storage scheme, the process of submission, negotiation and agreement of compensation events is fully documented in accordance with ECC. The process is carefully managed, monitored and reviewed by the project manager. Most importantly, the timely agreement of compensation events maintains confidence in the latest adjusted target cost and eases the project final account settlement process.

The strict response time frame of compensation events has also allowed advantageous alternative designs to be implemented on time and avoided abortive works, as demonstrated by the water harvesting system.

\subsection{Case study 2 - water harvesting system}

For the purposes of sustainable development in Hong Kong one of the missions of the DSD - the project manager introduced a new water harvesting system in the underground stormwater storage scheme.

The water harvesting system first collects water from various sources, including groundwater from the subsoil drainage system of the alternative foundation design and rainwater and surplus irrigation water underneath the turf. The system then utilises the 


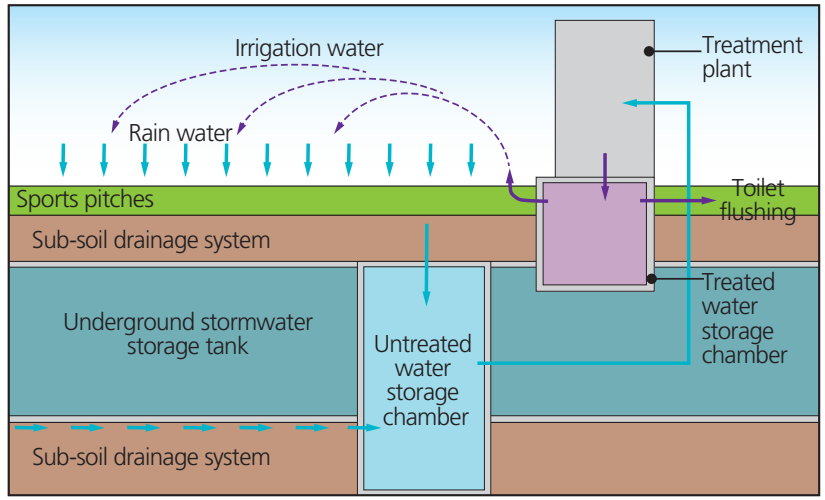

Figure 4. The water harvesting mechanism collects $220000 \mathrm{~m}^{3}$ of water per year - the largest such scheme in Hong Kong

water collected for general use at the recreational ground instead of discharging it into the sea (Figure 4).

Despite the complexity and innovative nature of the works, the contractor provided cost and time estimates of the proposed system promptly. This enabled the project manager to instruct the changes on time, avoiding both abortive works and impact to the programme.

The water collected from the water harvesting system is approximately $220000 \mathrm{~m}^{3}$ annually. To reduce the discharge volume to the sea and to make the best use of precipitation, the water collected is used for on-site irrigation of 11 sports pitches and toilet flushing at the Happy Valley recreation ground. The system is now the biggest water harvesting system in Hong Kong.

\section{Active subcontractor management}

Under traditional contracting arrangements, it is not uncommon to see contractors pursuing their own interests in selecting subcontractors, rather than focusing on the achievement of project objectives.

The underground stormwater storage scheme alleviates this problem by adopting a more active subcontractor management approach. This involves the project manager and the contractor jointly in the selection process of subcontractors.

The project manager and the contractor jointly prepare the subcontract specifications and conduct the tender briefings and tender interviews. A two-way discussion in the tender interviews encourages tenderers to raise questions and put forward innovative ideas using their expertise. This enables the tenderers to have a better understanding of the scope of works and any concerns that the employer and the contractor may have. The potential advantage is the return of a more realistic price that aligns with these parameters.

The underground stormwater storage scheme benefits from 'active subcontractor management' by enabling the project manager to capitalise on subcontractors' expertise. Tenderers are encouraged to raise questions on the tendered works, as well as proposing innovative solutions from their expertise during the tender interviews. An example of such an innovative solution is the alternative turf system.

\subsection{Case study 3 - alternative turf system}

The conforming design for an artificial turf system comprises a safety pad (the 'e-layer') under the turf layer for extra shock absorption. Following further clarification of the usage of the sport pitches by the project manager during the tender interview, some tenderers suggested an alternative artificial turf system that can offer a sufficient level of safety protection for football players without the e-layer. Finally, a new design was accepted with the advantages of a $20 \%$ cost saving and a shorter work duration.

\section{One team, one goal through $360^{\circ}$ communication network}

For enhancement of the NEC's required spirit of mutual trust and cooperation, the project manager has developed various innovative communication measures for improving communication among the whole project team, including the project manager, supervisors, contractor, subcontractors and key stakeholders.

The $360^{\circ}$ communication network is the principal innovative communication measure brought by the one team, one goal approach. This enables strong collaboration and efficient communication among the whole project team - the key to achieving success on this project.

The one team, one goal approach was adopted from the commencement of the contract. The project team works towards the achievement of common goals on time, cost, quality, safety and environment, which were agreed and established between the employer, the project manager, the contractor and the stakeholders at the beginning of the contract.

Under the $360^{\circ}$ communication network, various communication measures are implemented to ensure timely exchange of information and quick decisions. A joint office, joint organisation chart and regular management meetings are some of the measures adopted to expedite and strengthen communication between the employer and the contractor. Champion group meetings and partnering workshops are held to enhance mutual understanding and working relationships among different parties. A project $\log$ o and uniform is used to further nurture a sense of project ownership.

In addition, daily morning briefings are held on site, attended by approximately 30 members comprising the project manager, the contractor and the subcontractors for reviewing the works progress and upcoming activities. This also provides a platform for exchange of updated information or issues of concern among the parties. If any party issues an early warning notice, a risk reduction meeting is arranged to be held within $24 \mathrm{~h}$. The swift response ensures that risk is addressed promptly and that risk reduction measures are implemented without delay.

The highlight of the $360^{\circ}$ communication network implemented on the project is the use of different works-specific groups on the Whatsapp social media platform for instant and multi-directional communication. Various groups were set up among the project manager and his delegates, engineers, supervisors, contractor, foremen, subcontractors and stakeholders for instantaneous consultation and immediate notification. A list of these groups is shown in Table 2. 


\begin{tabular}{|c|c|c|c|}
\hline \multicolumn{4}{|c|}{ General groups } \\
\hline 1 & CW \& DSD HV Site & 5 & HV (Security Control Team) \\
\hline 2 & Bad Weather Action & 6 & $\mathrm{HV}(\mathrm{SE}-\mathrm{Al})$ the A-Team \\
\hline 3 & Knowledge Sharing Group & 7 & HVUSSS Management \\
\hline 4 & NEC Trio & 8 & HV - DP Management \\
\hline \multicolumn{4}{|c|}{ Works-related groups } \\
\hline 1 & Crescent Garden & 8 & Plant Rm \& Irrigation \\
\hline 2 & Storage Tank & 9 & Backstop \\
\hline 3 & DSD, CW \& ATAL (Pump house) & 10 & Broadwood Rd Sewage Works \\
\hline 4 & Box Culvert & 11 & Stage 2 storage tank \\
\hline 5 & Fan Room & 12 & Pipe M1 - M4 \\
\hline 6 & New Toilet Block & 13 & Hand Dug Construction \\
\hline 7 & Phase I Outstanding works & 14 & Happy Valley Turf System \\
\hline \multicolumn{4}{|c|}{ Interfacing groups } \\
\hline 1 & $\begin{array}{l}\text { DSD and LCSD - the Best } \\
\text { Partner }\end{array}$ & 3 & $\begin{array}{l}\text { HVUSSS DSD/HKJC/Contractors } \\
\text { Coordination }\end{array}$ \\
\hline 2 & E\&M Working Team & 4 & Subcontractors Interface Group \\
\hline \multicolumn{4}{|c|}{ Public relations groups } \\
\hline 1 & PR works in HVUSSS & 5 & Annual Media Briefing \\
\hline 2 & 528 HV Visit & 6 & 1/8 Football Match \\
\hline 3 & NEC Workshop & 7 & Partnering Workshop HV \\
\hline 4 & Xinhua Shooting & 8 & Special Event on $15 / 8$ \\
\hline \multicolumn{4}{|c|}{ Finance-related groups } \\
\hline 1 & Financial Team & 2 & Inventory (in/out record) \\
\hline
\end{tabular}

Table 2. List of Whatsapp groups

Recognising that the construction works would impact the community as a whole, stakeholder workshops and public briefings with local resident representatives, district council members, nearby schools and other organisations are held by the project manager. This provides opportunities for the stakeholders and the public to express any concerns, as well as for the project manager to explain the rationale and benefits that the underground stormwater storage scheme will bring on completion.

'Knowing me, knowing you' workshops are arranged by the DSD to help team members understand their counterparts' concerns in their duties or management. These workshops are triggered when a downtrend in the partnering scores rated by team members is observed. Following the workshops, in almost all cases the partnering score bounces back to the acceptable level. This enhances the team spirit to work towards the achievement of the common goal. On some occasions, an increase in work productivity is also observed.

The $360^{\circ}$ communication network, together with the early warning mechanism under the ECC, plays a vital role in risk management on the project. The following case study demonstrates how it works.

\subsection{Case study 4 - collaborative box culvert construction with HKJC}

Hong Kong Jockey Club is the biggest charity organisation in Hong Kong. Last year, it contributed HK\$3 billion ( $£ 270$ million)
The highlight of the $360^{\circ}$ communication network is the use of different works-specific groups on the Whatsapp social media platform for instant and multi-directional communication

to the local community, funded by its revenue raised from lotteries and horse racing operations.

The club holds horse racing events every Wednesday evening in Happy Valley during the racing season. The stakeholder is concerned that the construction works, particularly the construction of box culverts under the race track, would impact on the horse racing operations. To address this issue, the project manager, the contractor and the club adopt a 'multiple-parties collaboration' approach for expediting the works.

Firstly, the club made a special arrangement for extending the horse racing summer break in Happy Valley in 2014 from 2 months to 4 months. Secondly, the club instructed its contractors to complete their works according to a very tight schedule, providing the DSD's contractor 2 months for construction of the box culvert and 2 months for the re-turfing works. Thirdly, the DSD's contractor programmed its part of the box culvert connecting to club's box culvert at both ends to suit the club's works programme.

The project manager identified a high risk of traffic blockage during the summer break, due to the high traffic load of both DSD's and HKJC's contractors. Both contractors agreed on a gyratory traffic plan, jointly controlled by personnel of the two contractors. To facilitate the provision of this 'shared access', the project manager instructed a compensation event for the contractor to accelerate a section of the box culvert in order to ensure that the common access would be completed on time.

The DSD's contractor had possession of the works area where the advance works of the HKJC's contractor needed to be undertaken. To resolve this site possession problem, the parties reached a consensus that the DSD's contractor would provide excavation and lateral support works at the box culvert interface; this allowed the entry of the club's contractor on DSD's site to carry out its advance works.

The arrangement of shared access and shared excavation and lateral support arrangement was rare, if not the first of its kind, in the Hong Kong construction industry. Close and effective collaboration between the HKJC, the DSD and their respective contractors ensured that all the necessary preparation works were in place and thus minimised the risk of project delay.

Despite the passage of $20 \mathrm{~d}$ of very heavy rain and three typhoons during the construction period, the two large box culverts, which have a combined capacity equivalent to the total volume of 80 double-decker buses, were completed 2 weeks in advance of the planned completion date. Completion of the works was of paramount importance to the underground stormwater storage scheme as the works were critical for both the overall project programme and the scheduled horse racing operations. 


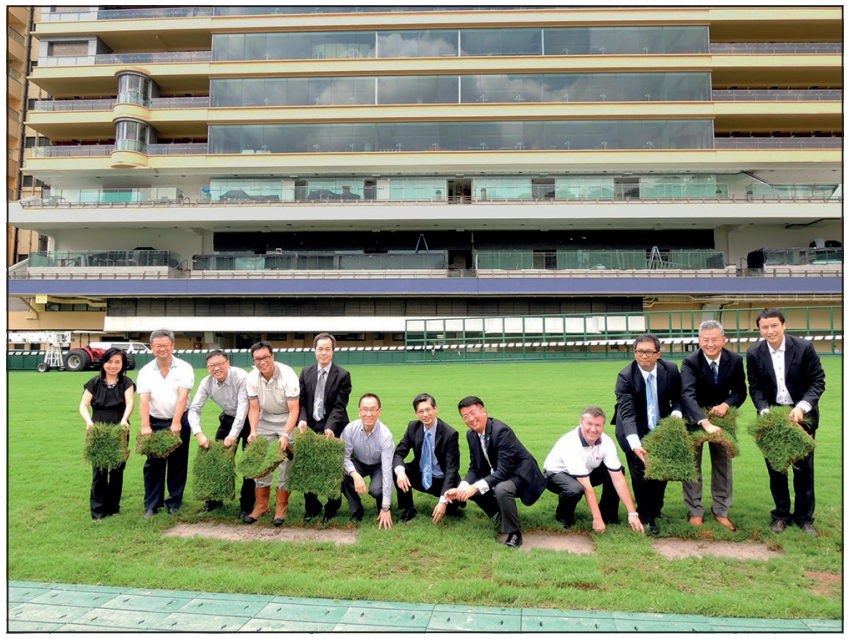

Figure 5. HKJC and DSD managers completing the turf over the new box culverts

Thanks to the collaborative approach adopted between the project team, the HKJC and the wider public, the horse racing track was re-opened on time (Figure 5).

Aside from horse racing operations, the construction works also mean the temporary closure of the ambulance track, a popular spot for jogging in the area used by approximately 300 to 500 joggers every day. Working together with the Wan Chai District Council and the Leisure and Cultural Services Department, the team explains to the public the rationale for the underground stormwater storage scheme and how the works will affect the facilities temporarily. They do this in several ways posters and notices are put up on site, newsletters are given to owner incorporations in the Happy Valley district, leaflets are handed out to Happy Valley recreation ground users and DSD staff members are stationed at relevant places to answer queries from the public in person.
The responses of the Happy Valley recreation ground users and residents of Happy Valley are supportive. Throughout the closure of the jogging facilities, no complaints have been lodged by the public.

\section{Conclusion}

The Happy Valley underground stormwater storage scheme is the largest NEC target cost contract awarded by the Hong Kong government to date. Further to the Drainage Services Department's experience on target cost contracts from its first NEC project, the Fuk Man Road nullah, the collaborative techniques under the one team, one goal approach developed under the underground stormwater storage scheme provides a source of experience that can feedback into future similar contracts.

The one team, one goal approach puts collaborative techniques, principally the $360^{\circ}$ communication network, into implementation. This provides instantaneous and multidirectional communication across the whole project team. A joint office, a common project logo, uniform and social gatherings attended by the project team members are some other examples of these collaborative techniques. Most importantly, the one team, one goal approach harmonises the common goals on time, cost, quality, safety, the environment and public relations between the employer, the project manager and the contractor.

Although traditional procurement is the most common procurement method in government projects for the reason of cost certainty, deficiencies around the lack of trust between parties, competitiveness on price but not value and limitations on continuous improvement have encouraged a change from traditional procurement to target cost contracts in Hong Kong. The underground stormwater storage scheme also extends the use of NEC3 contracts into the supply chain, as it is the first project in Hong Kong to trial the NEC3 Engineering and Construction subcontract.

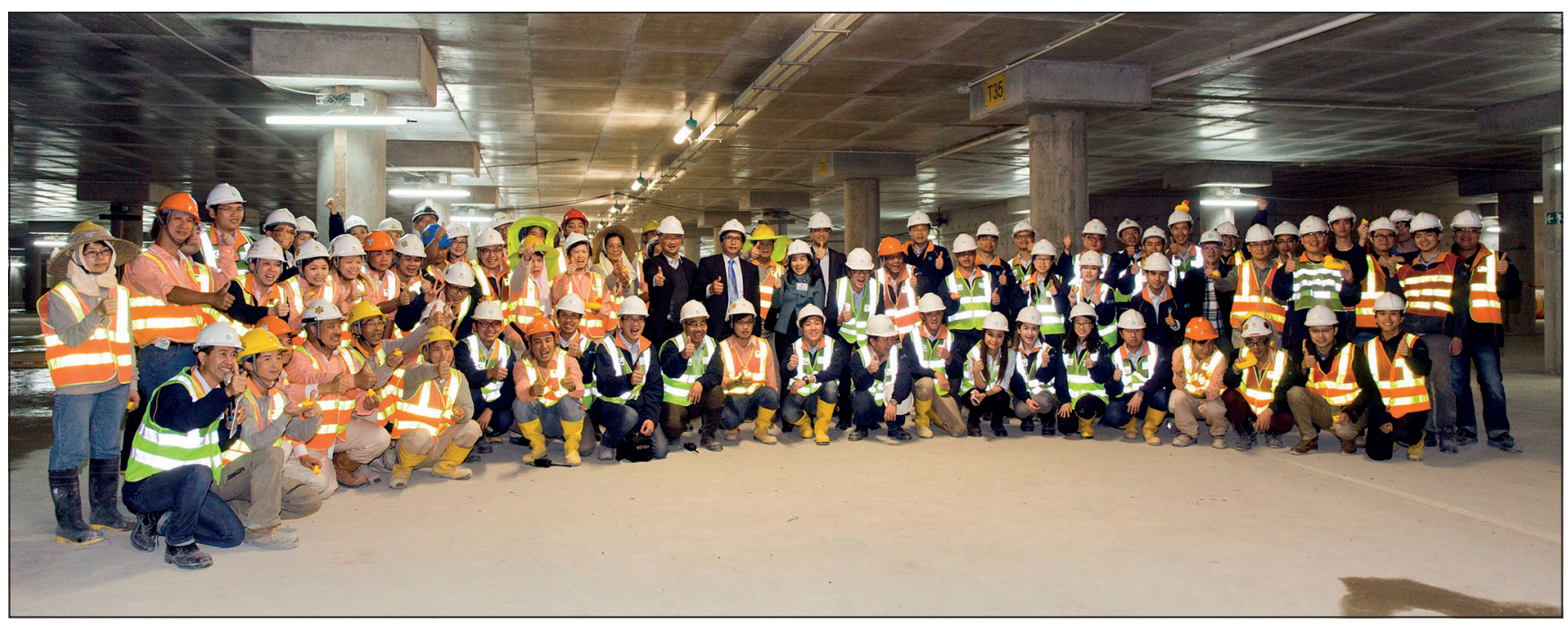

Figure 6. Project staff celebrate completion of phase 1 of the storage tank 


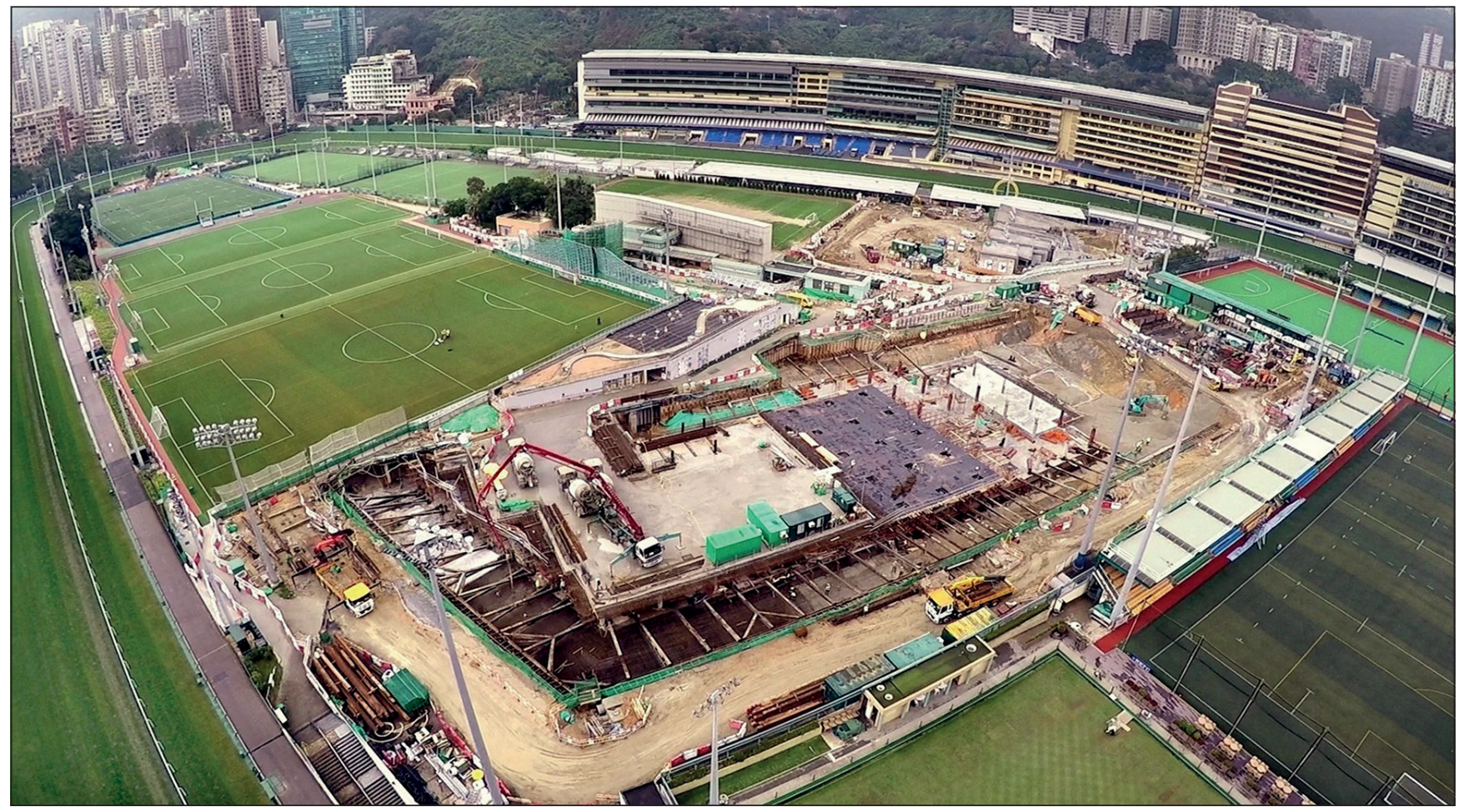

Figure 7. Phase 2 works will be completed in 2018 - the reinstated football pitches over phase 1 can be seen on the left

\subsection{Completion of phase 1 works}

Despite a higher than usual number of heavy rainstorms during the construction period, the phase 1 works $\left(30000 \mathrm{~m}^{3}\right.$ storage capacity) were completed 6 months in advance of the contractual completion date and came into operation in March 2015, just before the rainy season (Figure 6).

\subsection{Awards}

The underground stormwater storage scheme has won a number of green building, safety and environmental management awards since its commencement. Some of these major awards include

- platinum rating of Beam Plus by the Hong Kong Green Building Council

- merit award in the Green Building Award 2014

- Considerate Contractors Site Award Scheme 2013: gold Considerate Contractors Site Awards (Public Works - New Works); silver - Outstanding Environmental Management \& Performance Awards

- Considerate Contractors Site Award Scheme 2014: silver Considerate Contractors Site Awards (Public Works - New Works); gold - Outstanding Environmental Management \& Performance Awards

- Hong Kong Awards for Environmental Excellence 2014 silver award (construction industry).

The jewel of these awards was being highly commended for the NEC Large Project of the Year in April 2015. The judges commented
Using NEC with subcontractors supported by the knowing me, knowing you workshop really helped the whole team to collaborate and overcome numerous issues, typhoons and other challenges. Measurement and analysis of partnering scores amongst team members with corrective action taken to keep collaboration on track is considered best practice.

In addition to the above awards, China's Minister of Water Resources Chen Lei, Guandong Governor Zhu Xiaodan and other officials, in the company of the Permanent Secretary for Development Works Hon Chi-keung, Director of the Water Supplies Department Enoch Lam Tin-sing and Acting Director of the Drainage Services Department Mak Ka-wai, visited the site upon successful completion of the phase 1 works.

The successful story of underground stormwater storage scheme will continue until its completion in 2018 (Figure 7).

\section{Reference}

Challender J, Farrell P and Sherratt F (2014) Partnering in practice: an analysis of collaboration and trust. Proceedings of the Institution of Civil Engineers - Management, Procurement and Law 167(6): 255-264.

What do you think?

If you would like to comment on this paper, please email up to 200 words to the editor at journals@ice.org.uk.

If you would like to write a paper of 2000 to 3500 words about your own experience in this or any related area of civil engineering, the editor will be happy to provide any help or advice you need. 